\title{
Relationship value antecedents in the South African automotive component supply chain
}

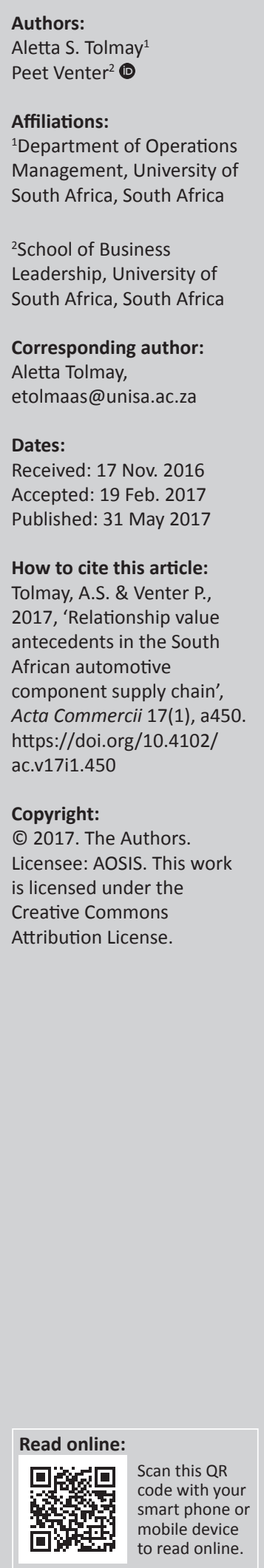

Orientation: Although literature agrees on the importance of 'relationship value', the term is still seen as ambiguous and authors fail to agree on its antecedents. Within a challenging global arena, relationship value is believed to result in business retention. It is therefore critical to have a better understanding of this value to ensure business sustainability within supply chains. Literature suggests that relationship value drivers comprise three dimensions, namely a core offering, sourcing process and customer operations.

Research purpose: The contribution of the research reported on in this paper is an enhanced conceptual understanding of relationship value and its salient drivers within the South African automotive supply chains.

Motivation for the study: Literature invites more research on relationship value and its drivers. Therefore, the research reported on tested the antecedents of relationship value.

Research design, approach and method: Relationship value drivers were tested through empirical research within the South African automotive supply chains by means of a path analysis. The research utilised a closed-ended questionnaire, and targeted managers among Tier 1 buyers and asked them about the relationship value traits of their best Tier 2 suppliers.

Main findings: It was found that personal interaction, which forms part of the sourcing process, is viewed as the strongest antecedent of relationship value within the South African automotive supply chains, followed by product quality and delivery.

Practical/managerial implications: It is suggested that superior supply chain practices within the South African automotive industry might secure business retention. Automotive component suppliers are therefore advised to implement relationship value strategies to promote higher value through personal interaction.

\section{Introduction}

The automotive industry faces numerous challenges such as technological challenges, ever more demanding clients, and shorter life and logistical cycles accentuated by the phenomenon of globalisation (Naude \& Badenhorst-Weiss 2011:71; Tolmay \& Badenhorst-Weiss 2015:3). The South African automotive industry is not exempt from these challenges. The industry is of utmost importance to the South African economy as the largest manufacturing sector (AIEC 2016:6). It is, therefore, important to identify innovative ways to differentiate and sustain automotive role players in this increasingly volatile and competitive global environment.

As product and price have become less important as differentiators, suppliers explore new ways to distinguish themselves through long-term relational exchanges (Ulaga \& Eggert 2006:119; Yeh 2016:138). Literature acknowledges buyer-supplier relationships within supply chains as a strategic asset with the potential of establishing competitive advantage (Ulaga \& Eggert 2006:119; Yeh 2016:138). A functioning buyer-seller relationship reduces the propensity for switching to alternative suppliers and increases commitment to the long-term relationship (Geiger et al. 2012:82). Long-term relationships are generally regarded as beneficial with the promise of customer retention (Pelser \& Mostert 2016:30). This long-term relationship approach is supported specifically for supply chain role players by Hohenthal, Johanson and Johanson (2014:11) who confirm that long-term supplier relationships result in increased relationship value (RV) with the consequential benefits of growth through increased business sustainability.

Relationship value is defined as the perceived benefits from a business relational exchange (Cheung, Myers \& Mentzer 2010:473; Ulaga \& Eggert 2006:128). The notion of RV and its importance for suppliers is widely supported in literature (e.g. Badenhorst-Weiss \& Tolmay 
2016:3; Hohenthal et al. 2014:4; Sun et al. 2014:81; Yeh 2016:139). However, RV from a supply chain customer's viewpoint is dynamic and, according to Ritter and Walter (2012:142), more research is required to better understand its drivers. Also, literature invites more research in general on supply chain relationships, especially within different countries and cultures (Mocke, Niemann \& Kotzé 2016:2).

There is a paucity of literature addressing RV and frameworks depicting value constructs (Rootman, Tait \& Sharp 2011:317), especially regarding $\mathrm{RV}$ drivers or antecedents ( $\mathrm{Li}$ et al. 2012:5456; Vos \& Kock 2013:858). Research on RV is also limited in terms of exploring diverse demographical subsamples such as different countries, procurement professionals and industries (Rootman et al. 2011:317). As no published studies could be found with a focus on South Africa, the aim of this paper is to present a better understanding of RV antecedents and consequences within the South African automotive supply chain.

As part of the theoretical background, the paper will reflect on the South African automotive supply chains and how the associated challenges are dealt with. The paper will advise on how these challenges can conceivably be overcome through the identification and management of RV constructs with the prospect of business expansion. Furthermore, RV and its contribution to business sustainability will be examined, followed by the rationale of the study and methodology. A path analysis will present more quantitative insight into RV antecedents and consequences. Finally, the findings, conclusions and recommendations will be presented to accentuate the importance of $\mathrm{RV}$ to automotive manufacturers as a differentiation strategy.

\section{The South African automotive supply chain}

The automotive industry is of utmost importance to the South African economy as it is the largest manufacturing industry in the country, is a large contributor towards job creation, and leads towards international competitiveness and growth (Badenhorst-Weiss \& Tolmay 2016:2). The industry contributed $7.5 \%$ towards the country's gross domestic product (GDP) in 2015 (AIEC 2016:6). The South African government is, therefore, actively involved in supporting the industry through various initiatives including trade policies (AIEC 2016:18).

The industry consists of a specialised tiered supply chain inclusive of automotive component suppliers and original equipment manufacturers (OEMs). OEMs constitute the actual car assemblers, which in South Africa include Toyota, Mercedes-Benz, BMW, Ford, Nissan, Volkswagen and General Motors (AIEC 2016:13; Badenhorst-Weiss \& Tolmay 2016:2). The OEMs source complete subassemblies or modules, such as interiors and electronics, from approximately 500 automotive component suppliers (AIEC 2016:7).
Globalisation, accentuated by technological changes with regard to the offering of services and products, poses challenges to these organisations, especially with regard to supply chain relationships (Cheung et al. 2010:472). For example, South African automotive component suppliers are faced with the problem of increased commoditisation of products and services. These challenges include amplified risks such as strong competition, downward pressure on prices, reduced production and logistical turnaround times, increased quality requirements and demands for more environmentally friendly products (Ambe 2014a:1539).

In order to sustain business, automotive component suppliers need to seek alternative and creative ways to add more value than their global peers. With little room for differentiation through product quality, price and logistics, component suppliers are only left with a means to differentiate themselves through RV (Yeh 2016:137). It is, therefore, important for suppliers to understand RV antecedents (Ritter \& Walter 2012:142) as RV holds the promise of growth and the realisation of more and longer lasting business (Hohenthal et al. 2014:11).

In this study the focus was on the relationships between buyers in Tier 1 of the supply chain, and their perspectives on the relations value offered by their Tier 2 suppliers ${ }^{1}$.

\section{Relationship value}

The term 'value' often is used without considering the meaning and context of this complex concept. Value is a dynamic multifaceted and subjective concept with different interpretations. It is often conceptualised as a trade-off between benefits and sacrifices (Barry \& Terry 2008:229; Ritter \& Walter 2012:137; Sun et al. 2014:79; Vos \& Kock 2013:849) and is constantly compared to the value of alternatives in the market (Ulaga 2003:678; Ulaga \& Eggert 2004:314). The creation of value, resulting in business retention (Ambe \& Badenhorst-Weiss 2011:348; Rootman et al. 2011:318), is increasingly seen as the next source of competitive advantage. Thus, Ulaga and Eggert (2004:311) believe that perceived value directly influences a customer's intention to sustain business with suppliers through a longterm relationship.

The relationship between customer and supplier must provide value for both parties to be beneficial and sustainable (Ritter \& Walter 2012:136; Vos \& Kock 2013:849). The manufacturing supply chain (and by implication the automotive supply chains) is characterised by the preference to forge strong long-term relationships with fewer suppliers (Ambe 2014a:1539; Cadden, Marshall \& Cao 2013:87; Yeh 2016:138). As a result, the manufacturer or customer is faced with decisions to invest in new supplier relationships, to maintain and develop valued relationships, or alternatively to terminate low-value relationships in favour of more

1.Tier 1 suppliers provide components or modules to OEMs for the assembly of finished products. Tier 2 suppliers, in turn, supply raw materials or components to Tier 1 suppliers. 
promising ones - a process referred to as relationship governance (Yeh 2016:138).

However, perceived value cannot be divorced from the actual relationship (Vos \& Kock 2013:849). RV is defined as the perceived benefits, both tangible and intangible, in a relational exchange (Cheung et al. 2010:473; Ulaga \& Eggert 2006:128), and refers to the perceived net worth of tangible benefits that can be obtained over the duration of the relationship (Hogan 2001:341; Yeh 2016:139). Tangible benefits include cash, improved process efficiency and product quality, as well as technology transfer (Hogan 2001:341). However, Hogan (2001:349) states that intangible benefits, including satisfaction and commitment, can also be realised from the long-term relationship. With this promise of increasing business performance and sustainability, the concept of RV should not be taken lightly.

Relationship value has been analysed in the literature from both the view of the seller (supplier) and the buyer (customer) (Ritter \& Walter 2012:136). This article focuses on the buyer's perspective and on customer perceived value, which is presented as the trade-off between benefits and sacrifices within the relationship (Ritter \& Walter 2012:137; Ulaga \& Eggert 2006:128). For RV to exist, the perceived benefits must exceed the perceived sacrifices. In this study, the sacrifice dimensions were not considered, as key sacrifice aspects, such as price, are determined by the buyer during the tender process, and suppliers are contractually required to annually reduce prices for the duration of the contract (Tolmay 2012:243). In other words, price is not considered as a differentiator.

Accordingly, only the benefits of RV will be addressed. Authors generally agree that the beneficial outcome of RV is in the form of business sustainability where the client is willing to continue and even expand the relationship, that is, RV leads to trust, customer commitment and retention (Barry \& Terry 2008:232; Geiger et al. 2012:90; Parry et al. 2012:890; Sun et al. 2014:80; Walter et al. 2003:159; Yeh 2016:140).

Ulaga and Eggert (2006:128) and Eggert, Ulaga and Schultz (2006:21) present three antecedents of RV. Firstly, the core offering is made up of product quality and delivery performance. In the context of the automotive industry, this antecedent translates into the production of components according to agreed specifications and delivering them timeously to the site where assembly takes place. Second is the sourcing process, which encapsulates the service support offered by the seller to the buyer and personal interaction between representatives of the seller and the buyer. The final antecedent refers to customer operations comprising the perceived know-how of the seller and its ability to improve the time-to-market performance of the buyer (Eggert et al. 2006). Various authors broadly agree with these three antecedents and their underlying dimensions (e.g. Barry \& Terry 2008:229-232; Coenen, Von Felten \& Waldburger 2012:110; Eggert et al. 2006:21; Ulaga \& Eggert 2006:128).
During the literature review, various shortcomings in extant literature pertaining to RV were identified, providing the rationale for the empirical research reported on in this paper. Authors tend to agree that RV and the definitions in general should be further explored (Hohenthal et al. 2014:10; Li et al. 2012:5457; Ritter \& Walter 2012:142; Sun et al. 2014:79), and call for more conceptualisation (Hohenthal et al. 2014:17; Vos \& Kock 2013:858; Yeh 2016:150). Figure 1 depicts the more specific research opportunities relating to RV identified by various authors.

While the buying decision-making process has been theorised, more research regarding the buying decisionmaking dimensions in the business-to-business environment (B2B) is required (Jansen van Rensburg, Venter \& Strydom 2010:5).

In addition, further research on buyer-seller relationships is called for (Barry \& Terry 2008:228; Ulaga \& Eggert 2006:120) given its importance in business and supply chain relationships (Hohenthal et al. 2014:4) and its potential for improving business retention (Sun et al. 2014:92).

With RV as a complex and situated concept, there is a demand for more research in different contexts; that is, research situated in different markets, countries and cultures (Hohenthal et al. 2014:17; Sun et al. 2014:95; Vos \& Kock 2013:858; Yeh 2016:150). It might therefore be necessary to formulate different strategies for different offerings in diverse industries as it is important to understand the customer's operations and to provide value to the customer (Sun et al. 2014:94; Yeh 2016:150) (Figure 1). In addition, BadenhorstWeiss and Tolmay (2016:10) expressed a specific need to explore RV in the South African automotive supply chain. Finally, Palmatier et al. (2006:136) as well as Vos and Kock (2013:858) specifically call for research to predict RV antecedents (Figure 1).

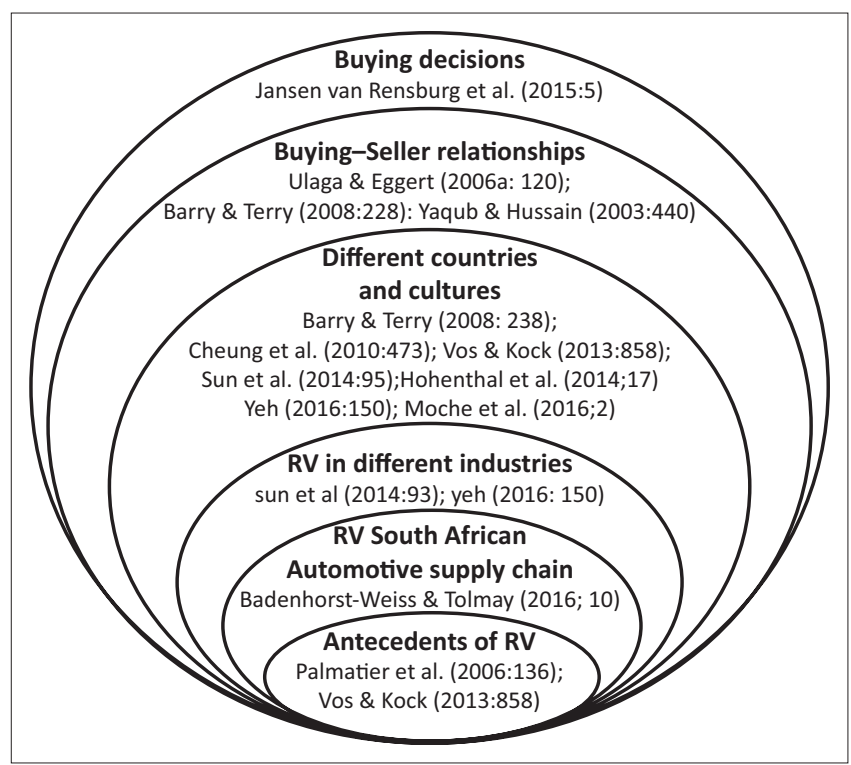

FIGURE 1: Relationship value research opportunities identified from the literature. 
As stated earlier in this paper, Mocke et al. (2016:2) call for more supply chain relationship research in different countries and cultures, and similarly Rootman et al. (2011:317) call for more research, also in specific industries. The unique contribution of this research is that it was undertaken in a developing country that is dissimilar to the context of most preceding research. This quantitative research aims to offer more insight into RV and its antecedents in the South African automotive industry, with a specific focus on the relationship between Tier 1 buyers and Tier 2 suppliers.

\section{Research methods}

The research was conducted utilising a survey among Tier 1 buyers on RV and its various antecedents as it applies to their Tier 2 suppliers.

A structured questionnaire was compiled using a survey instrument (Eggert et al. 2006:26; Ulaga \& Eggert, 2006: 134-135) related to the three value drivers of RV, namely core offering, sourcing process and customer operations, as a basis. The questionnaire utilised a seven-point measurement scale in line with the research of Eggert et al. (2006:22), ranging from $1=$ 'strongly disagree' to $7=$ 'strongly agree'. In preparation for the research, a questionnaire validation process was conducted with industry experts in the South African automotive supply chain. The purpose of this process was to determine whether the questions were applicable in the South African automotive supply chain context and to identify additional constructs unique to the context. Following the finalisation of the questionnaire, an e-mail invitation, containing a link to the Web-based survey hosted by SurveyMonkey, was sent to the sampling frame. Nonresponses were contacted telephonically to encourage them to participate in the research.

The survey targeted managers among Tier 1 buyers in the South African automotive supply chain who are members of the National Association of Allied and Automotive Component Manufacturers (NAACAM). E-mails were forwarded to all the managers listed on the NAACAM membership list, representing a total of 146 managers. This membership list of managers therefore represented the sampling frame. The survey requested managers to indicate their designation as either; CEO/Senior manager, Technical manager or Administrative/Procurement manager. A total of 119 respondents, representing the three types of senior decision makers, completed the questionnaire. The completed responses represent a response rate of $81.4 \%$.

The data analysis included an exploratory factor analysis (EFA) to explore the interrelationships among a set of variables/items and also to confirm the underlying factor structure (Pallant 2011:181). The EFA was followed by a path analysis approach. Although the authors considered the concerns of Cole and Preacher (2014:300-315) regarding path analyses, it was decided to utilise this method because of its simplicity and the restricted sample size. Furthermore, it was utilised only to determine variation.

\section{Research findings}

The dependent variable (RV) utilised a three-item scale obtained from the questionnaires of Ulaga and Eggert (2006:135) and Eggert et al. (2006:22), respectively. The RV scale revealed a high Cronbach's alpha coefficient $(0.812$, see Table 1) and exceeded the generally agreed-upon lower limit Cronbach's alpha of 0.70 for internal consistency (Pallant 2011:303).

For the independent variables, EFA was employed to identify the hypothetical construct factors underlying the data. A total of 16 items were included in the factor analysis, and it was found that four factors explain a cumulative $72 \%$ of variance in the scale response. The extracted four factors represent product delivery and quality (F1), personal interaction (F2), product development support (F3) and improving time-tomarket (F4) (Table 1 for EFA results).

To aid in the interpretation and scientific utility of these four components, Varimax rotation was performed. The rotated solution revealed the presence of a simple structure (Thurstone 1947), with each of the four components showing a number of strong loadings (Table 1). Orthogonal rotation was chosen as the analytical procedures for these solutions are better developed than those of Oblique rotation. The Varimax rotation method was specifically chosen as it results in a clearer separation of factors (Pallant 2011:185). For the extraction method, the set of items were subjected to Principal Axis Factoring (PAF) using SPSS18.0 software to extract communalities.

Preliminary analyses were performed to ensure that there are no violations of the assumptions of normality, linearity and homoscedasticity. Inspection of the correlation matrix (Table 2) revealed the presence of many coefficients of 0.5 and higher, motivating the suitability for factor analysis. Additionally, the Kaiser-Meyer-Olkin value was 0.898, exceeding the recommended minimum value of 0.6 (Kaiser 1970, 1974), while the Bartlett's Test of Sphericity (Bartlett 1954) reached statistical significance $(p<0.001)$, further supporting the factorability of the correlation matrix.

Product delivery and quality (F1) comprises those items that relate to the technical performance of the supplier, such as product quality, reliability and delivery performance. Given that this is the prime reason why suppliers are appointed in the industry, it is no surprise that suppliers rated highest on this aspect (factor mean $=5.791, \mathrm{SD}=0.988$ ).

Personal interaction (F2) relates to the personal relationship that the supplier has with the buyer, and includes aspects like information sharing and how the client is treated. The factor mean is 5.697 ( $\mathrm{SD}=0.968)$. The personal interaction scale was obtained from the studies of Ulaga and Eggert (2006:135) and Eggert et al. (2006:22). For personal interaction, the number of items was reduced from seven to four with the aim of compiling a shorter questionnaire and preventing duplication (Table 1). These items were tested 
TABLE 1: Factors.

\begin{tabular}{|c|c|c|c|c|c|c|}
\hline Constructs and questions & Factor loadings & $\begin{array}{l}\text { Cronbach's alpha for } \\
\text { construct }\end{array}$ & $\begin{array}{l}\text { Mean of individual } \\
\text { items }\end{array}$ & $\begin{array}{l}\text { Standard deviation } \\
\text { for individual items }\end{array}$ & Factor mean & $\begin{array}{l}\text { Standard deviation } \\
\text { for factor }\end{array}$ \\
\hline Relationship value & - & 0.812 & - & - & 5.741 & 0.860 \\
\hline $\begin{array}{l}\text { Our organisation gains value from the } \\
\text { relationship with supplier A }\end{array}$ & 0.658 & - & 5.728 & 1.033 & - & - \\
\hline $\begin{array}{l}\text { When comparing all costs and benefits involved } \\
\text { in our relationship with Supplier A, my firm feels } \\
\text { that Supplier A creates value for us }\end{array}$ & 0.541 & - & 5.544 & 1.122 & - & - \\
\hline $\begin{array}{l}\text { The relationship my firm has with Supplier A is } \\
\text { valuable to us }\end{array}$ & 0.695 & - & 5.947 & 0.875 & - & - \\
\hline F1-Product delivery and quality & - & 0.930 & - & - & 5.791 & 0.988 \\
\hline $\begin{array}{l}\text { Supplier } A \text { has the ability to secure product } \\
\text { quality consistency. }\end{array}$ & 0.780 & - & 5.798 & 1.122 & - & - \\
\hline $\begin{array}{l}\text { Supplier A provides acceptable delivery accuracy } \\
\text { (no missing or wrong parts). }\end{array}$ & 0.780 & - & 5.737 & 1.153 & - & - \\
\hline Supplier A offers product reliability. & 0.753 & - & 5.904 & 0.892 & - & - \\
\hline $\begin{array}{l}\text { Supplier A makes minimal delivery errors (late, } \\
\text { wrong address, wrong products). }\end{array}$ & 0.737 & - & 5.561 & 1.255 & - & - \\
\hline Supplier A has minimal product rejects (faulty). & 0.607 & - & 5.868 & 1.035 & - & - \\
\hline Supplier A has the ability to address problems. & 0.590 & & 5.832 & 1.017 & - & - \\
\hline F2-Personal interaction & - & 0.904 & - & - & 5.697 & 0.968 \\
\hline $\begin{array}{l}\text { Supplier A has the ability to provide us with } \\
\text { appropriate information. }\end{array}$ & 0.745 & - & 5.842 & 1.001 & - & - \\
\hline $\begin{array}{l}\text { Supplier A has the ability to give us a feeling of } \\
\text { being treated as an important client. }\end{array}$ & 0.740 & - & 5.728 & 1.131 & - & - \\
\hline Supplier A offers good working relationships. & 0.703 & - & 5.779 & 1.041 & - & - \\
\hline $\begin{array}{l}\text { Supplier A has the ability to provide general } \\
\text { know-how. }\end{array}$ & 0.588 & - & 5.434 & 1.217 & - & - \\
\hline F3-Product development support & - & 0.888 & - & - & 5.285 & 1.269 \\
\hline $\begin{array}{l}\text { Supplier A has the ability to assist with new } \\
\text { product development. }\end{array}$ & 0.871 & - & 5.446 & 1.446 & - & - \\
\hline $\begin{array}{l}\text { Supplier A has the ability to help us speed up } \\
\text { product development. }\end{array}$ & 0.715 & - & 5.257 & 1.357 & - & - \\
\hline $\begin{array}{l}\text { Supplier A has the ability to drive innovation in } \\
\text { products. }\end{array}$ & 0.606 & - & 5.173 & 1.433 & - & - \\
\hline $\begin{array}{l}\text { Supplier A has the ability to help us to improve } \\
\text { the cycle time of all activities in the } \\
\text { manufacturing process. }\end{array}$ & 0.758 & - & 4.982 & 1.395 & - & - \\
\hline $\begin{array}{l}\text { Supplier A has the ability to improve our time-to- } \\
\text { market. }\end{array}$ & 0.722 & - & 5.088 & 1.373 & - & - \\
\hline
\end{tabular}

The mean for each item was calculated, and the mean of the item means in a construct was used as the factor mean. These mean scores served as proxy measures of the factors and were used as the observed variables in the path analysis.

The correlations between factors were calculated using Pearson's correlation coefficient.

TABLE 2: Pearson's correlation.

\begin{tabular}{|c|c|c|c|c|c|}
\hline Pearson's correlation & $\begin{array}{c}\text { Relationship value } \\
\text { (RV) }\end{array}$ & $\begin{array}{l}\text { Product quality and delivery } \\
\text { (F1) }\end{array}$ & $\begin{array}{c}\text { Personal interaction } \\
\text { (F2) }\end{array}$ & $\begin{array}{l}\text { Product development support } \\
\text { (F3) }\end{array}$ & $\begin{array}{l}\text { Improve time-to-market } \\
\text { (F4) }\end{array}$ \\
\hline Relationship value (RV) & - & - & - & - & - \\
\hline $\begin{array}{l}\text { Product quality and delivery } \\
\text { (F1) }\end{array}$ & $0.728 \dagger$ & - & - & - & - \\
\hline Personal Interaction (F2) & $0.774 \dagger$ & $0.709 \dagger$ & - & - & - \\
\hline $\begin{array}{l}\text { Product development } \\
\text { support (F3) }\end{array}$ & $0.586 \dagger$ & $0.629 \dagger$ & $0.649 \dagger$ & - & - \\
\hline Improve time-to-market (F4) & $0.571 \dagger$ & $0.529 \dagger$ & $0.579 \dagger$ & $0.557 \dagger$ & - \\
\hline
\end{tabular}

$\dagger$, All correlations were significant at a 0.05 level (two-tailed).

during the pilot study with industry experts to ensure that the correct attributes were being tested. The factor still revealed acceptable internal consistency (Cronbach's alpha $=0.904)($ Table 1$)$, confirming that all items measured the same attribute (Pallant 2011:6).

The next factor product development support (F3) encompasses the extent to which the supplier assists the buyers in developing their products, while improve time-tomarket (F4) relates to the extent to which the supplier assists the buyers in getting their products to market quicker.
The means for these two factors are $5.285(\mathrm{SD}=1.269)$ and 5.044 (SD = 1.270), respectively. Respondents seemed to generally rate suppliers lower on these two latter factors.

When assessing the standard deviation for the four factors, it was found that there is a similar variation across the means.

All correlations were larger than 0.5 and were, therefore, considered to be strong (Cohen 1988:79-81; Pallant 2011:134). While these results provide insight into the strength of the underlying bivariate relationships, the aim was to identify 


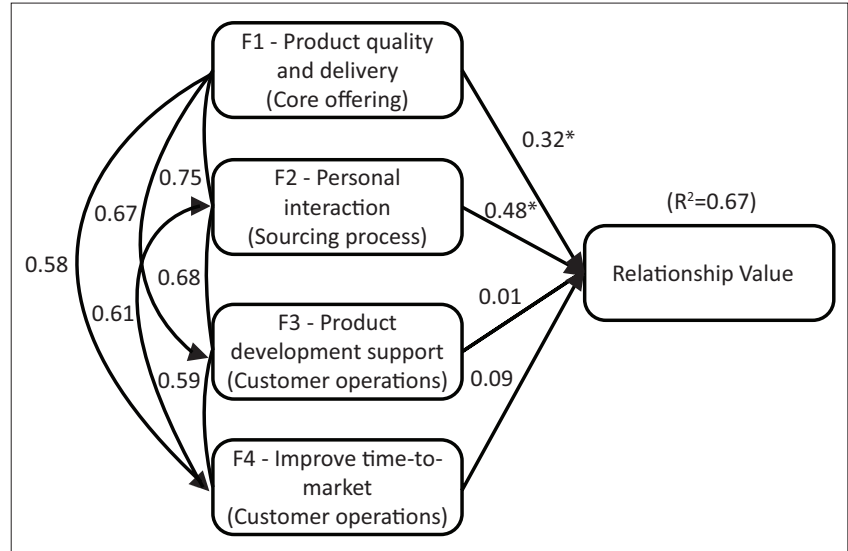

*, Significance $p<0.05$.

FIGURE 2: Results of the path analysis. Standardised coefficients are presented in the paths to relationship value.

those variables that contribute to explaining variation in RV from a multivariate perspective. For this reason, a path analysis was conducted to determine the strength of the various factors as predictor variables and their relationship in explaining variation in RV.

The results of the path analysis with the standardised regression coefficients ( $\beta$ coefficients) are presented in Figure 2.

The results indicate that product quality and delivery (F1) and personal interaction (F2) have the strongest direct effects on RV ( $\beta=0.32$ for $\mathrm{F} 1$ and $\beta=0.48$ for F2, $p<0.05)$. However, product development support (F3) and improved time-tomarket $(\mathrm{F} 4)$ do not appear to significantly influence RV directly $(\beta=0.01$ for $\mathrm{F} 3$ and $\beta=0.09$ for $\mathrm{F} 4, p<0.05)$, suggesting that these variables may be mediated by F1 and F2. The R-square measure indicates that $67 \%$ of the variance in RV can be explained by the model (Figure 2). The correlational relationships between the independent variables (left on Figure 2) revealed acceptable discriminant validity $(r<0.90)$ (Pallant 2011:151) and suggested sufficient independence between factors.

\section{Discussion and findings}

The path analysis indicated that personal interaction (F2) was the strongest predictor of the dependent variable, RV. Therefore, personal interaction (F2) is deemed a salient antecedent of $\mathrm{RV}$ and is a stronger predictor of $\mathrm{RV}$ than product and delivery quality (F1). This might be expected, as product quality and delivery (F1) comprises the primary tasks of a supplier in this industry, namely producing quality goods and delivering them on time. In other words, suppliers have a better opportunity to differentiate themselves in their personal interaction with clients than with their core products. Product development support (F3) and improved time-to-market (F4) were not statistically significant predictors of RV.

The literature review identified three antecedents of RV, namely, the core offering, sourcing process and customer operations. However, the research reported in this article identified factors slightly different from these generally accepted antecedents. In this study, personal interaction (F2) emerged strongly as a predictor, rather than merely being part of the broader sourcing process.

This finding corresponds with the USA-based findings of Ulaga and Eggert (2006:130) and Eggert et al. (2006:24), who found that the sourcing process is the strongest relational aspect resulting in perceived RV. However, these authors categorised personal interaction as a subset of the sourcing process. Specifically aiming to measure personal interaction, they utilised the items of Ulaga and Eggert (2006:130) and Eggert et al. (2006:24), as the researchers viewed these as the most relevant items relating to the variable for this study. Similar to this study, Ulaga and Eggert (2006:125) found that personal interaction (F2) enhances good working relationships and is highly regarded and viewed as an important value creator. Personal interaction in the B2B environment is associated with good personal relationships, the provision of valuable advice and problem-solving, and is viewed as important in different national contexts (Wuyts, Verhoef \& Prins 2009:42).

This study therefore confirms that personal interaction contributes the most towards RV in the South African automotive supply chain. This finding is revealing as the automotive supply chain is generally strongly driven by technical performance measures such as products, logistics and quality.

\section{Conclusion and recommendations}

Supply chains in South African are faced with global challenges, and role players are forced to seek new ways to differentiate and sustain business. With limited room for differentiation, automotive component suppliers are left with the RV to add more value. Because literature suggested that further research should be undertaken to conceptualise RV, it formed the focus of the empirical research reported on in this paper.

The findings suggest that personal interaction is viewed as the strongest antecedent of RV in the South African automotive supply chain (Std. $\beta=0.48$ as per Figure 2). Personal interaction forms part of the sourcing process, and therefore the most value is added during this process.

The results indicate that personal interaction is a more important direct predictor of RV in automotive supply chains than actual product delivery and quality. In line with the findings presented in Table 3, personal interaction encourages good working relationships, know-how, provision of appropriate information and treating customers in a way that makes them feel valued and important. Automotive component suppliers are therefore advised to implement RV strategies in order to ensure sustainability. These RV strategies should mainly enhance personal interaction through the associated behaviour depicted through the items in Table 3. The enhancement of RV promises to not only retain but even to expand business where customers will provide more orders to the supplier. However, it should also be noted that product 
quality and delivery (F1) correlates highly with personal interaction (F2) and should accordingly remain a key focus area. The remote variables (product development support, F3, and improve time-to-market, F4) exert a strong influence on the perceptions of personal interaction and product delivery performance, respectively, and help buyers to do better business (e.g. by also providing general know-how - F1, item 4), thus providing a significant means of improving the personal interaction between buyer and supplier.

This study contributed towards better understanding the conceptualisation of $\mathrm{RV}$ and its antecedents in the South African automotive supply chain. With this improved understanding of $\mathrm{RV}$, automotive component suppliers are able to increase RV towards the requirements of the customer. However, it must be mentioned that this study targeted a relatively small population identified from the NAACAM membership list. Although the majority of Tier 1 suppliers are listed as NAACAM members, not all Tier 1 suppliers are represented by NAACAM. This study also leaves space for further research, as discussed below.

As personal interaction was identified as a salient antecedent, further research on the conceptualisation of personal interaction is suggested. More quantitative research studies may shed more light on the perception of $\mathrm{RV}$ within automotive supply chains. Alternative RV constructs may also be included in the equation to determine the effect on RV. In addition, similar research may also be undertaken on different tiers within the South African automotive supply chains.

This study thus found that superior supply chain practices in the South African automotive industry appreciate the salient RV antecedent - personal interaction - to secure business sustainability. With the stated importance of RV and the promise to secure business sustainability, it can be argued that relationships will prove to be beneficial to the South African automotive component suppliers.

\section{Acknowledgements}

Credit must be given to a consultant Dr Dion van Zyl who assisted with statistical data analysis and interpretation.

\section{Competing interests}

The authors declare that they have no financial or personal relationships that may have inappropriately influenced them in writing this article.

\section{Authors' contributions}

Both authors contributed equally to the study.

\section{References}

AIEC, 2016, Automotive export manual 2016 - South Africa, Zest (Pty) Ltd, Pretoria.

Ambe, I.M., 2014a, 'Difficulty to overcome supply chain challenges faced by vehicle manufacturers in South Africa', Journal of Applied Business Research 30(5), 1539-1550. https://doi.org/10.19030/jabr.v30i5.8806
Ambe, I.M. \& Badenhorst-Weiss, J.A., 2011, 'South African automotive industry: Trends and challenges in the supply chain', Journal of Contemporary Management 8, 337-362.

Badenhorst-Weiss, J.A. \& Tolmay, A.S., 2016, 'Relationship value, trust and supplier retention in South African automotive supply chains', Journal of Applied Business Research 32(5), 1-11. https://doi.org/10.19030/jabr.v32i5.9762

Barry, J. \& Terry, T.S., 2008, 'Empirical study of relationship value in industrial services', Journal of Business \& Industrial Marketing 23(4), 228-241. https://doi. org/10.1108/08858620810865807

Bartlett, M.S., 1954, 'A note on the multiplying factors for various chi square approximations', Journal of the Royal Statistical Society 16(Series B), 296-298.

Cadden, T., Marshall, D. \& Cao, G., 2013, 'Opposites attract: Organisational culture and supply chain performance', Supply Chain Management: An International Journa 18(1), 86-103. https://doi.org/10.1108/13598541311293203

Cheung, M.S., Myers, M.B. \& Mentzer, J.T., 2010, 'Does relationship learning lead to relationship value? A cross-national supply chain investigation', Journal
of Operations Management 28(6), 472-487. https://doi.org/10.1016/j.jom. of Operations

Coenen, C., Von Felten, D. \& Waldburger, D., 2012, Beyond financial performance: Capturing relationship value in FM. The added value of facilities management: Concepts, findings and perspectives, Polyteknisk Forlag, Denmark, pp. 105-122.

Cohen, J.W., 1988, Statistical power analysis for the behavioral sciences, 2nd edn., Lawrence Erlbaum Associates, Hillsdale, NJ.

Cole, D.A. \& Preacher, K.J., 2014, 'Manifest variable path analysis: Potentially serious and misleading consequences due to uncorrected measurement error', Psychological Methods 19(2), 300-315. https://doi.org/10.1037/a0033805

Eggert, A., Ulaga, W. \& Schultz, F., 2006, 'Value creation in the relationship life cycle: A quasi-longitudinal analysis', Industrial Marketing Management 35(2006), 20-27. https://doi.org/10.1016/j.indmarman.2005.07.003

Geiger, I., Durand, A., Saab, S., Kleinaltenkamp, M., Baxter, R. \& Lee, Y., 2012, 'The bonding effects of relationship value and switching costs in industrial buyer-seller relationships: An investigation into role differences', Industrial Marketing Management 41(1), 82-93. https://doi.org/10.1016/j.indmarman.2011.11.013

Hogan, J.E., 2001, 'Expected relationship value: A construct, a methodology for measurement, and a modeling technique', Industrial Marketing Management 30(4), 339-351. https://doi.org/10.1016/S0019-8501(01)00152-3

Hohenthal, J., Johanson, J. \& Johanson, M., 2014, 'Network knowledge and businessrelationship value in the foreign market', International Business Review 23(1) 4-19. https://doi.org/10.1016/j.ibusrev.2013.08.002

Jansen van Rensburg, M.J., Venter, P. \& Strydom, J.W., 2010, 'Approaches taken by South African advertisers to select and appoint advertising agencies', Southern African Business Review 14(1), 1-26.

Kaiser, H.F., 1970, 'A second-generation little Jiffy', Psychometrica 35(4), 401-415. https://doi.org/10.1007/BF02291817

Kaiser, H.F., 1974, 'An index of factorial simplicity', Psychometrica 39, 31-36. https:// doi.org/10.1007/BF02291575

Li, L., Ford, J.B., Zhai, X. \& Xu, L., 2012, 'Relational benefits and manufacturer satisfaction: An empirical study of logistics service in supply chain', International Journal of Production Research 50(19), 5445-5459. https://doi.org/10.1080/0020 7543.2011.636388

Mocke, K., Niemann, W. \& Kotzé, T., 2016, 'The role of personal relationships between buyers and suppliers of third-party logistics services: A South African perspective', Acta Commercii 16(1), 1-13. https://doi.org/10.4102/ac.v16i1.367

Naude, M.J. \& Badenhorst-Weiss, J.A., 2011, 'Supply chain management problems at South African automotive component manufacturers', Southern African Business Review 15(1), 70-99.

Pallant, J., 2011, SPSS Survival Manual 4th edition: A step by step guide to dato analysis using SPSS version 18, Open University Press, Maidenhead, Berkshire.

Palmatier, R.W., Dant, R.P., Grewal, D. \& Evans, K., 2006, 'Factors influencing the effectiveness of relationship marketing: A meta-analysis', Journal of Marketing 70(4), 136-153. https://doi.org/10.1509/jmkg.70.4.136

Parry, S., Rowley, J., Jones, R. \& Kupiec-Teahan, B., 2012, 'Customer-perceived value in business-to-business relationships: A study of software customers', Journal of Marketing Management 28(7-8), 887-911. https://doi.org/10.1080/026725 7X.2012.698637

Pelser, C. \& Mostert, P.G., 2016, 'Relationship intention and satisfaction as predictors of wholesale and retail customers' loyalty towards their training providers', Southern African Business Review 20(1), 29-50.

Ritter, T. \& Walter, A., 2012, 'More is not always better: The impact of relationship functions on customer-perceived relationship value', Industrial Marketing Management 41(1), 136-144. https://doi.org/10.1016/j.indmarman.2011.11.020

Rootman, C., Tait, M. \& Sharp, G., 2011, 'Bank managers' views on relationship marketing', Journal of Contemporary Management 8, 315-336.

Sun, P.C., Pan, F.T., Wu, P.C. \& Kuo, C.C., 2014, 'An empirical study of B2B relationship valueoffering type as a moderator', Journal of Business Studies Quarterly 6(1), 79-97.

Thurstone, L.L., 1947, Multiple factor analysis, University of Chicago Press, Chicago, IL.

Tolmay, A.S., 2012, 'Developing a relationship value model for the South African business to business automotive supply chain', DBL dissertation, University of South Africa.

Tolmay, A.S. \& Badenhorst-Weiss, J.A., 2015, 'Supply chain relationships between first and second tier suppliers in South African automotive supply chains: A focus on trust', Journal of Transport and Supply Chain Management 9(1), 1-8. https://doi. org/10.4102/jtscm.v9i1.205 
Ulaga, W., 2003, 'Capturing value creation in business relationships: A customer perspective', Industrial Marketing Management 32, 677-693. https://doi. org/10.1016/j.indmarman.2003.06.008

Ulaga, W. \& Eggert, A., 2004, 'Relationship value and relationship quality', European Journal of Marketing 40(3/4), 311-327. https://doi.org/10.1108/ 03090560610648075

Ulaga, W. \& Eggert, A., 2006, 'Value-based differentiation in business relationships: Gaining and sustaining key supplier status', Journal of Marketing 70(1), 119-136. https://doi.org/10.1509/jmkg.2006.70.1.119

Vos, M. \& Kock, A., 2013, 'Impact of relationship value on project portfolio success Investigating the moderating effects of portfolio characteristics and external turbulence', International Journal of Project Management 31(6), 847-861. https://doi.org/10.1016/j.ijproman.2012.11.005

Walter, A., Müller, T.A., Helfert, G. \& Ritter, T., 2003, 'Functions of industrial supplier relationships and their impact on relationship quality', Industrial Marketing Management 32(2), 159-169. https://doi.org/10.1016/S0019-8501(02)00230-4

Wuyts, S., Verhoef, P.C. \& Prins, R., 2009, 'Partner selection in B2B information service markets', International Journal of Research in Marketing 26(1), 41-51. https://doi. org/10.1016/j.ijresmar.2008.07.008

Yeh, Y.P., 2016, 'Critical influence of relational governance on relationship value in strategic supply management', European Business Review 28(2), 137-154. https:// doi.org/10.1108/EBR-09-2014-0068 